\title{
Analysis on the Development Problems and Solutions of the Real Estate Industry from the Perspective of Public Economy
}

\author{
Hongyu Pan \\ Southwest Minzu University, Chengdu, China \\ Email: 609055434@qq.com
}

How to cite this paper: Pan, H.Y. (2021) Analysis on the Development Problems and Solutions of the Real Estate Industry from the Perspective of Public Economy. Open Access Library Journal, 8: e7782.

https://doi.org/10.4236/oalib.1107782

Received: July 23, 2021

Accepted: August 13, 2021

Published: August 16, 2021

Copyright $\odot 2021$ by author(s) and Open Access Library Inc.

This work is licensed under the Creative Commons Attribution International License (CC BY 4.0).

http://creativecommons.org/licenses/by/4.0/

\begin{abstract}
With the continuous development of social economy and urbanization, increasing demand for housing, thus the real estate industry has developed rapidly. As the limited housing supply can not meet too much housing demand, forming the contradiction between excess demand and supply shortage, the housing price in the real estate market is also gradually increasing. The rapid development of the real estate market also leads to the emergence of some phenomena. The soaring housing price has become a common phenomenon in the real estate market. The rising housing price affects all aspects of social development and has a significant impact on the life of members of society. From the perspective of public economics, housing has the attribute of public goods, and people lack of understanding of this attribute, coupled with some irregularities in the market, which is not conducive to the development of China's real estate industry. Based on the perspective of public economics, the paper analyzes the problems of the real estate market and puts forward corresponding countermeasures.
\end{abstract}

\section{Subject Areas \\ Public Economics}

\section{Keywords}

Public Economics, Public Goods, Real Estate Market, Question, Solution

\section{Introduction}

In the process of China's rapid social and economic development, the development of real estate industry occupies a leading position, which affects the development of other industries from all sides, and promoting the high-quality de- 
velopment of real estate industry plays an important role for the whole society. China is a large population with a broad land area and society and economy has also achieved rapid development. Housing is people's basic living needs. The development of the real estate industry has performed well and has walked out of the development of the real estate industry with Chinese characteristics. Today, the real estate industry has become a relatively heavy part of the position in China's economic development, affecting China from finance, investment and other aspects. The development of the real estate industry has not only played a huge role in promoting the growth of gross national product, promoted the urbanization process, promoted the common development of all walks of life, but also improved the people's lives. However, the rapid development of the real estate industry also leads to some problems and deficiencies, which have a certain negative effect on the healthy and stable development of the industry. We should pay attention to the existence of these problems, take measures to solve them as soon as possible, to promote the high-quality development of the real estate industry.

\section{Real Estate Industry from the Perspective of Public Economics}

With the rapid advancement of Chinese urbanization and the rapid development of the real estate industry, the demand for housing increases, and housing has gradually become an indispensable necessity in people's daily life. From the perspective of public economics, housing is a daily necessity with the property of public goods. Public goods have non-competitive and beneficial non-exclusive characteristics, the marginal cost of providing goods and services to a given production level is zero and no one can exclude the consumption of public goods because of their own consumption. [1] Public goods can be divided into pure public goods and quasi-public goods. Pure public goods refers to everyone's consumption of this product and will not lead to reduced consumption of the product, is non-competitive, non-exclusive and cannot be divided, while quasi-public goods have limited noncompetitive or limited non-exclusive, and its nature is also between "public" and "private". Housing is a special public good, and compared with other public goods, although housing is not absolutely exclusive, and will not appear the obvious externality characteristics in the allocation of resources, housing is a basic necessity of life. Nowadays, more and more people regard housing as an investable commodity, ignoring the public goods properties of housing. Due to the rapid development speed of China's real estate industry, the operation mechanism of the real estate market needs to be further improved.

\section{Problems Existing in the Real Estate Industry}

\subsection{The Real Estate Market Supply Structure Is Unreasonable}

The types of urban housing in China are mainly composed of commercial and noncommercial housing. Non-commercial housing mainly includes low-rent housing and affordable housing. They are houses directly invested by the government 
or given certain preferential and subsidy policies, used to provide livable housing or rental housing for low and middle-income groups, to meet the basic living security for this population. Commercial housing is all kinds of housing independently developed by all kinds of real estate developers, mainly for consumers of the middle and high-income classes. With the development of economic and social and the increase of population, residents' demand for housing is expanding, large city real estate developers are large, and high housing prices, low and medium price, commercial housing and affordable housing supply, but small city population is not high, it is difficult to attract foreign housing demand, causing a large number of commercial housing sales, forming inventory. On the one hand, the house is vacant, but on the other hand, the people who really need housing to stop, and the housing problem of the working class is difficult to solve, which sets obstacles to the sustainable and healthy development of the housing factory industry. [2]

\subsection{Change in the Purpose of the Real Estate Market Demand}

Nowadays, owning a house to live is people's basic living needs, but with the development of society and economy, people gradually change from having a house to live to owning a house to invest. This transformation also promotes the rapid development of China's real estate industry to some extent. As China's real estate industry plays a very important role in China's economic development, more and more people recognize the investability and importance of housing. People regard buying housing as a steady means of investment, leading to the increasing popularity of the property investment boom and the rising prices of housing. The characteristics of real estate integrating consumer goods and investment property make real estate developers and speculation classes focus on the pursuit of interests. In order to make huge profits, real estate enterprises expect a new round of real estate market to come, in order to wait for the price to rise, deliberately hoard inventory, cover houses not to sell. Facing the high rate of return in the real estate industry, the investment tendency to be developed for development makes the high proportion of new homes vacant and speculation more common. As more and more people regard buying housing as a way of investment, people increasingly ignore the essential attribute of housing to provide accommodation, and the purpose of buying housing changes from meeting basic living needs to fixed asset investment.

\subsection{The Real Estate Market Development Is Not Sound}

In recent years, the development of real estate industry has played an important role in promoting the social economy. As China has not yet formed a perfect housing management system in law and system, some businesses speculate, raising housing prices, operating the market and other phenomena occur from time to time. As the main factor affecting the supply of real estate, its unique scarcity and irreplaceable nature are destined to meet the market-oriented housing demand. 
The development of the real estate industry is closely related to the land management. When carrying out housing construction projects, a lot of land needs to be used, and the effective use of the land also needs to rely on the development of real estate. However, for the actual situation of the development of China's real estate industry in China, there is a great contradiction between land demand and the supply of land. The contradiction between the two is precisely caused by the unsound development of China's real estate market, which is an urgent problem to be solved in the current development of China's real estate industry. [3] In the later stage of the development of the real estate industry, the government should pay more attention to high-quality development and regulate the bad phenomena in the real estate market.

\section{Solutions}

\subsection{Adjust the Supply Structure of the Real Estate Market}

The real estate industry plays a very important role in the development of social economy, and promoting the high-quality development of the real estate industry is conducive to the high-quality development of social economy. The reasonable supply structure of the real estate market should match the supply speed, construction time sequence and population urbanization process of commercial housing. The government should take certain measures to adjust the supply structure of the real estate market according to the changes in the real estate market. When vigorously developing the real estate market, the government should speed up the improvement of supporting services for public facilities such as education, medical care, leisure and entertainment, so that the development of urban supporting functions matches the development of housing opening. [4] Under a reasonable real estate market supply structure, real estate developers should optimize the residential product structure and apartment structure to meet people's different types of housing needs. In addition, real estate developers should also increase the innovation of residential products, from only providing living space to providing a high quality of life, and promote the integration of housing and health care, tourism and leisure, community services.

\subsection{Stabilize the Market Demand of the Real Estate Industry}

The Chinese government is taking effective measures to macro-control the real estate industry to promote the rationality of housing prices and the healthy and stable development of the real estate industry. At the present stage, China is vigorously promoting the provision of affordable housing, urban renewal and upgrading of existing housing, and the renovation of old urban residential areas. Having a house to live is people's basic living needs. Housing is used to live rather than for people to invest and make profit. The government adopts effective measures to control the upsurge of "property speculation", fully implement the long-term management and control mechanism to stabilize land prices, housing prices and expectations, and promote the high-quality development of the real 
estate market. [5] The government has gradually strengthened the regulation and management of housing prices, so that housing prices can return reasonably, and more people can have houses to live in. Reasonable housing prices make residents' demand for housing more stable, and promote the healthy and stable development of China's real estate industry.

\subsection{Improve the Development of the Real Estate Market}

As a complete industry system, a real estate industry should improve the legal basis of relevant regulations on real estate management, establish a systematic, complete form and scientific laws and regulations system, and enhance the coordination of real estate legislation with other legal provisions. First, the establishment of a diversified real estate financial system is necessary to promote the sound development of the real estate market, so that investors in the real estate market can enter and leave in an orderly and controlled manner, and strictly control the quality of investment. For example, real estate investment funds can be established, which can reduce investors with idle funds and effectively control the speculation system. [6] Secondly, the government can appropriately increase the supply of land for housing construction projects, prompting a greatly increase the supply of housing. When the housing supply is sufficient, the competition between the real estate developers will reduce the cost of building houses, in order to reduce the housing prices. Finally, the sound development of the real estate market is inseparable from the macro-control of the government. It should not only regulate the order of the real estate market, but also stimulate the vitality of the real estate market and promote its stable and healthy development.

\section{Summary}

The development of the real estate industry is of great significance for promoting the development of China's social economy, but in the rapid development of the problems of the real estate industry. We should fully understand the public goods of the property of housing, so that more people can have a house to live, to meet people's basic living needs. The high-quality development of the real estate industry is related to people's lives. The government should take effective measures to carry out macro-control to achieve the healthy and stable development of the real estate industry. The property of public products is the basic property of housing. Analyze the problems of the real estate industry from the perspective of public economics, combined with the current actual situation, put forward effective solutions, which is conducive to promoting the high-quality development of the real estate industry. This paper only analyzes the problems existing in the real estate industry from the perspective of public economy, and the development of this industry affects all aspects of social and economic development. The subsequent research should study the real estate industry from multiperspectives and put forward its own suggestions to promote the sustainable and healthy development of the real estate industry. 


\section{Conflicts of Interest}

The author declares no conflicts of interest.

\section{References}

[1] Wang, H.Y. and Sun, Y. (2014) On the Principle of Public Economics. China Collective Economy, No. 19, 14-15.

[2] Liu, H. (2016) On the Principle of Public Economics. China Management Information Technology, 19, 131.

[3] Song, Z.M. (2019) Analysis on Current Situation and Trend of Real Estate Economy in China. Modern Business, No. 25, 61-62.

[4] Feng, K. (2019) Research on Real Estate Industry. Housing \& Property, No. 36, 1-2.

[5] Zhao, L. (2019) Development Trend-Oriented and Implementation Path of China's Real Estate Industry. Green Environmental Protection Building Materials, No. 12, 226.

[6] Lv, X.F. (2020) Current Developments and Trends of the Real Estate Industry. Residential \& Property, No. 30, 1-2. 